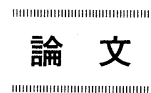

\title{
セルロース系バイオマスの加圧熱水による 糖化打よびアルコール発酵
}

- 1997.9.22 受理一

\begin{abstract}
九州工業技術研究所*1 坂木 剛, 柴田 昌男, 三木 敏晴, 安田 誠二 鹿児島県工業技術センター*2 廣末 英晴

佐賀大学*3 林 信行
\end{abstract}

\section{1.はじめに}

エタノールの製造法としては，合成法と発酵法があ り，前者は石油から得られるエチレン，後者は糖質系， デンプン系扰よびセルロース系のバイオマスから得ら れるへキソースを原料としている。石油資源に関して は，その価格および供給の不安定さと共に資源の枯渇 が危惧されており, 今後は再生可能なバイオマスを原 料とすることか望ましい。またエ夕ノールをガソリン や灯軽油に代わるクリーンな液体燃料と位置付けるな ら，バイオマス資源の中でも大量に入手可能なセル ロース系バイオマスを原料とするプロセスを実用化す る必要があろう。

セルロース系バイオマスをアルコール発酵原料とす るためには，まずセルロースを覆うリグニンを除去し， 糖化のための反応媒体がセルロースに接触できるよう にしなければならない。またセルロースの糖化に関し ては, 酵素分解法や酸を触媒とする加水分解法か試み られているが，それぞれ，セルロースの強固な結晶構 造のために処理速度が遅いことや, 反応器の腐食, 廃 液処理の問題が残されており，こうした理由のため, セルロース系バイオマスをアルコール発酔原料とする ことは未だ工業化されるに至っていない1)。

Bobleter $ら^{2) 3)}$ は, 加圧された $100^{\circ} \mathrm{C}$ 以上の液体状 態の熱水 (加圧熱水) が持つ高いイオン積 ${ }^{4)}$ を利用し, 酸を加えることなく水のみでセルロースを加水分解す るプロセスを提案した。また, Antal ら ${ }^{5) 6)}$ は, セル

*1 佐賀県鳥栖市宿町807-1

*2 鹿児島県姶良郡隼人町小田

*3 農学部 佐賀県佐賀市本庄 1 番地
ロース系バイオマスから，リグニン，へミセルロース を除去する工程に加圧熱水を利用することを検討した。 こうした検討はいずれも $300^{\circ} \mathrm{C}$ 以下の熱水を用いて行 われたが, 阿尻ら ${ }^{7)}$ は水の臨界温度 $\left(374^{\circ} \mathrm{C}\right)$ 付近に おけるセルロース加水分解の反応速度論的解析を行い, その分解が極めて高速に進行する事を示した。そこで, 我々はこの触媒を使わない加圧熱水分解法を新しい糖 化法として捉え, $250-405^{\circ} \mathrm{C}$ の広い温度範囲にわたっ てセルロース粉末およびイタジイ (広葉樹の一種) 木 粉の分解特性, および分解物のアルコール発酵性を調 ベ，七ルロース系バイオマスのアルコール発酵原料へ の転換法として，本法の適用可能性を検討した。

\section{2. 実験方法}

\section{1 試 料}

セルロース系バイオマスの主構成成分であり，かつ ヘキソースの供給源であるセルロースとして, カラム 用微結晶セルロース粉末 $(100-120 \mu \mathrm{m}$, フナコシ

(株)）を，また，セルロース系バイオマスとして， 広葉樹の一種であるイタジイを用いて分解特性掞よび 分解物のアルコール発酵性を調べた。ただし, イタジ イは, JISP8010に従って, ベンゼン・エタノール混合 溶剂（容積比 $2 ： 1$ ）で樹脂および脂肪分を抽出除去 した木質粉末 $(150-500 \mu \mathrm{m})$ を試料とした。この時 のイタジイの抽出率は乾燥試料基準で $5.4 \%$, また JISP8008に準じて72\%硫酸不溶分として求めたリグニ ング量は27\%であった。ただし，27\%中にはタンニン も含まれる。本報では差引73\%をホロセルロースとし て考えた。 


\section{2 加圧熱水分解}

Fig. 1 に示す反応器（内容積 $6 \mathrm{ml}$, SUS316製) に 乾燥した試料粉末 $0.5 \mathrm{~g}$ と蒸留水 $3.0 \mathrm{~g}$ を仕込み, 反応 器内の空気を不活性ガスとして炭酸ガスを用いて置換 した後，炭酸ガスを $1 \mathrm{~kg} / \mathrm{cm}^{2} \mathrm{G}$ チャージして反応器 を密閉した。反応器を $250^{\circ} \mathrm{C} に$ 加熱された予熱用塩浴 中に投入し， 3 分間振とうさせながら予熱した後，引 き続いて所定温度に加熱された反応用塩浴中に移し， ここで更に所定時間振とう加熱して反応させた。その 後直ちに反応器を水浴に入れて急冷し, 反応を終結さ せた。ただし，イタジイの場合，セルロースより分解

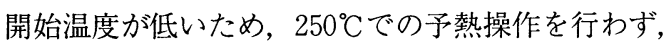
反応器を直接反応用塩浴に投入して反応を行った。反 応後はFig. 2 に示す手順で分解物の分画を行った。 まず，反応器内のガスを排出した後内容物を蒸留水で 洗い出し, 濾過して得た濾液の水を減圧蒸留で留去し, 水可溶分（WS）を採取した。その収率を求めると共 に，高速液体クロマトグラフィー（HPLC）による組

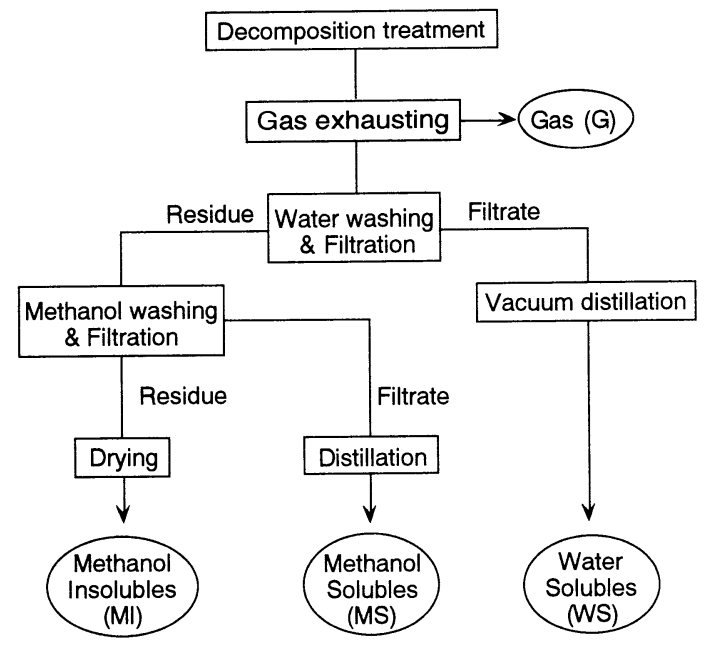

Fig.2 Analytical procedure after decomposition treatment

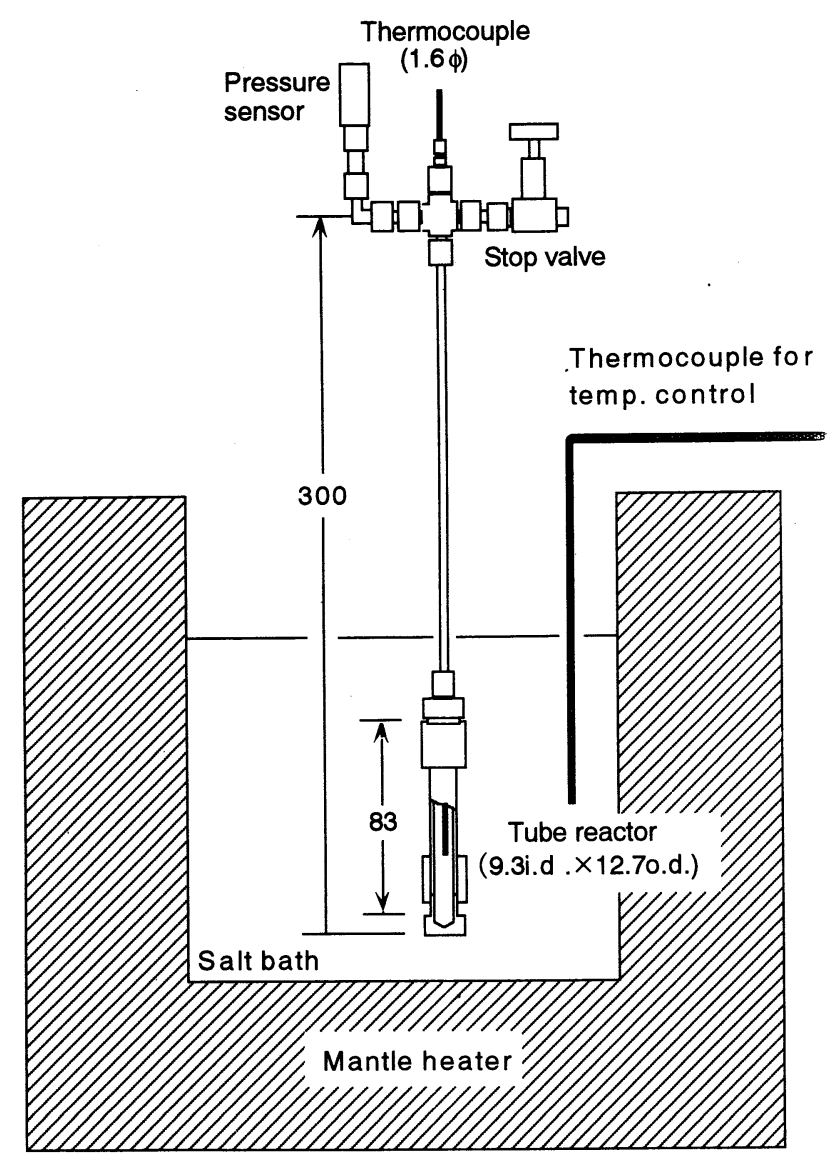

Fig.1 Apparatus for decomposition of biomass 
成分析を行った。また，水不溶の残渣についてはメ夕 ノールで洗浄し, 同様にメタノール可溶分 (MS) と メタノール不成分（MI）を採取し，ガスおよび減圧 蒸留時に失われる揮発成分 ( $\mathrm{G}$, 重量損失) と共にそ れぞれの収率を求めた。水の減圧蒸留時に失われる成 分としては, 蒸留前後の HPLC 解析の結果, フルフ ラール等が認められ，その量は反応初期では無視でき るが反応後期は数\%に達した。また，イタジイから得 られたWS，MS，MIの一部については赤外吸収スペ クトル（FTIR）の測定を行った。

\section{3 分解物の性状解析}

WS の組成分析に用いた HPLC は，2 本のカラム (SECW12+SECW13，横河（株）製）と2つの検出 器（UV (254 nm）＋RI）を備えたシステムであり， 水とアセトニトリルの混合液（容積比 $7: 3$ ）を溶出 液とし, その供給速度 $0.8 \mathrm{ml} / \mathrm{min}$, カラム温度 $40^{\circ} \mathrm{C} に$ て操作した。各成分の定量は RI のピークから内部標 準法により行った。また，赤外吸収スペクトルの測定 はパーキンエルマー社製 SPECTRUM2000を用い, $\mathrm{KBr}$ ディスク法により測定した。

\section{4 アルコール発酵}

得られた水溶性分解物の醅母による発酵試験を行っ た。ただし，水可溶分中には発酵阻害物質であるフル フラール類 ${ }^{8)}$ が数\%生成していたため，これを予め活 性炭で除去した水溶液を発酵用原液とした。この原液 $50 \mathrm{ml}$ に，ポリペプトン，酵母エキス， $\mathrm{KH}_{2} \mathrm{PO}_{4}$ ，お お よび $\mathrm{MgSO}_{4}$ をそれぞれ $1.0 ， 0.5 ， 0.5$ ，㧍よび0.2 wt\%になるように加えた後，オートクレーブにて $121^{\circ} \mathrm{C} ， 20$ 分の滅菌処理を行った。これに0.1N- $\mathrm{NaOH}$ を加えて $\mathrm{pH}$ を 6.0 に調整し，1 白金耳(約 $1 \times$ $10^{7} \mathrm{cell} / \mathrm{ml}$ ) の酵母 (Saccharomyces cerevisiae, IFO 0216) を植菌し, $30^{\circ} \mathrm{C} に て$ 静置培養した。発酵過程は, 炭酸 ガス生成による試料の重量減少で観測し，また，発酵 前後の試料のヘキソース量および生成エタノール量を HPLCにより求めた。

\section{3. 結果と考察}

\section{1 セルロースの糖化および発酵}

セルロースの分解速度は加熱温度が高いほど早いが, その分解挙動は加熱温度によらずほぼ同じである ${ }^{910) 。 ~}$ セルロースの代表的分解挙動例を Fig. 3 に示す。こ れは反応用塩浴温度を $305^{\circ} \mathrm{C}$ とした時の結果であるが， 温度の上昇と共にセルロースは急速に加水分解して水

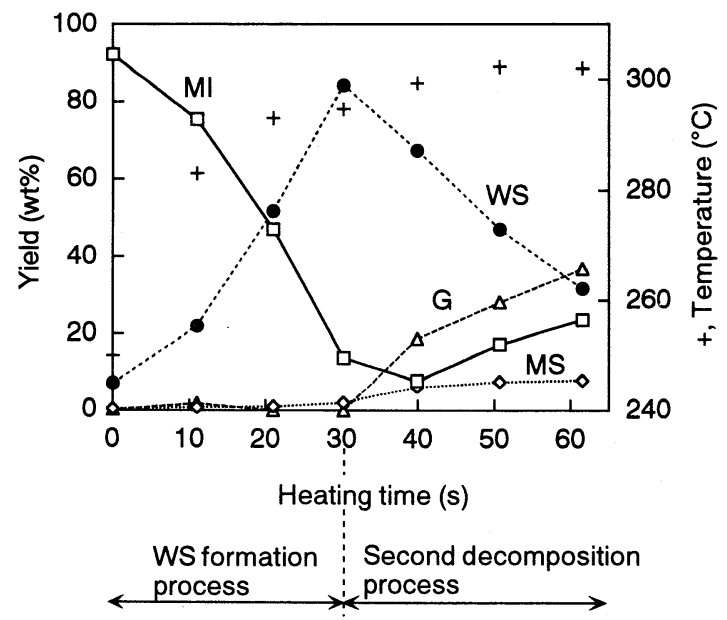

Fig.3 Decomposition behavior of cellulose in hot compressed water

(Temp. of salt bath for reaction, $305^{\circ} \mathrm{C}$ )
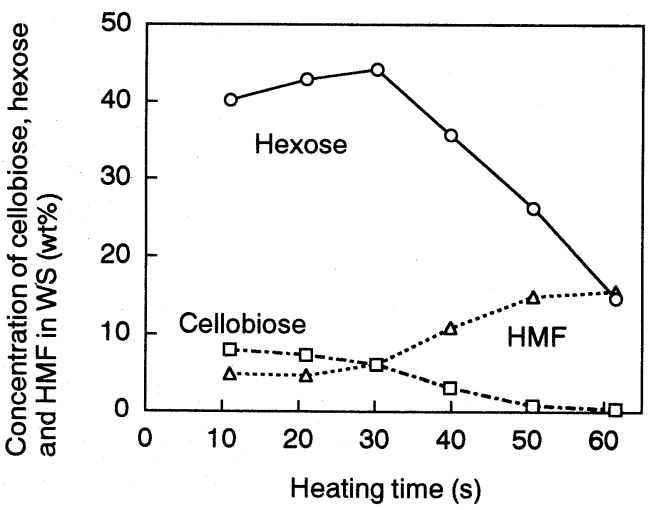

Fig.4 Change in composition of WS from cellulose with heating time

(Temp. of salt bath for reaction, $305^{\circ} \mathrm{C}$ )

可溶化される (WS 生成過程)。生成したWS は引き 続いて二次分解され，ガスおよび非水溶性の MS 成分 に転化される(二次分解過程)。反応用塩浴温度が $305-405^{\circ} \mathrm{C}$ の範囲では, WS の最大収率は加熱温度に 関係なく約 $80 \%$ であり，その時の加熱時間は13-30秒 であった ${ }^{9)}$ 。WS の組成は, Fig. 4 にその例を示すよ うに, 反応初期は単糖のヘキソース（大部分グルコー スで若干のフルクトースを含む)，拉よび二糖（セロ ビオース）から六糖までのオリゴ糖が主体であったが, 反応後期は糖類が減少し，ヒドロキシメチルフルフ ラール（HMF）等の二次分解物が多くなった。

セルロース基準で表したへキソースの生成量と加熱 


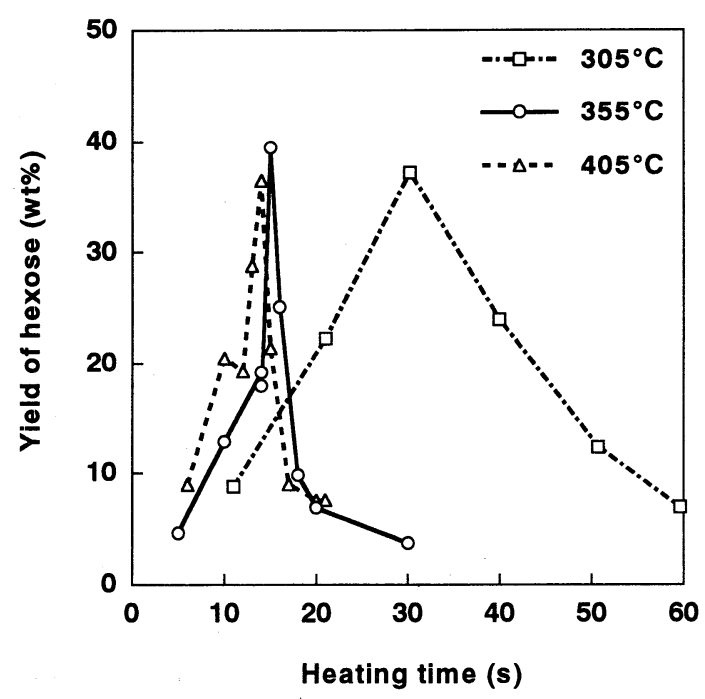

Fig.5 Relationship among hexose formation from cellulose, heating time and heating temperature

時間，および加熱温度（反応用塩浴温度）の関係を Fig. 5 に示す。加熱温度を高くするとへキソースの 生成速度は早くなるが, ヘキソースの生成量には大差 がなかった。従って，それぞれの温度で加熱時間を調 整すれば，七ルロースから発酵可能成分であるへキ ソースが40 wt \% 近い高収率で得られることがわかっ た。

MI に関しては，IR スペクトルでその性状を調べた が9，WS 生成過程における MI は白ないし灰色のセ ルロースの末反応残渣であり，一旦消失した後二次分 解過程で再び生成する MI は, MS 成分がさらに重質 化した黒いチャーあった。

ヘキソースの発酵は次式に従って進行する。

$$
\mathrm{C}_{6} \mathrm{H}_{12} \mathrm{O}_{6} \rightarrow 2 \mathrm{C}_{2} \mathrm{H}_{5} \mathrm{OH}+2 \mathrm{CO}_{2}
$$

そこで発酵時の重量減少から発生炭酸ガスのモル数 を計算し, 発酵用原液中のへキソースに対するモル比 が発酵時間と共に 2 に近づく過程を観測した。加熱時 間 $10 \mathrm{~s}$, 到達温度 $330^{\circ} \mathrm{C}$ の処理で得られた分解物水溶液 の発酵試験結果を Fig. 6 に示す。この図には比較の ため, 活性炭処理を行っていない分解物水溶液, およ び純粋なグリルース水溶液の発酵データも合わせて示 してある。加圧熱水処理により得られたセルロースの 分解物水溶液は，このままでも発酵可能であったが, 活性炭によりフルフラール類を除去する事により，そ の発酵速度は純粋なグルコース水溶液とほほ同程度に まで改善されることが認められた。なお，確認のため

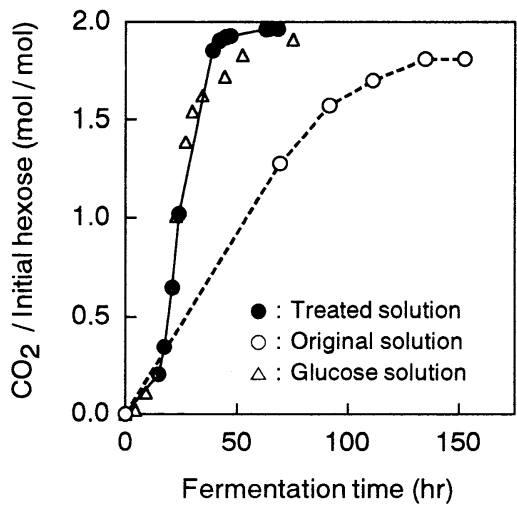

Fig.6 Fermentation of water soluble fractions from cellulose

エ夕ノールの生成量を HPLC で測定した結果, 消費 ヘキソース量に見合う量のエタノールが生成しており， 良好な物質収支が成立している事か確認できた。

\section{2 イタジイの糖化および発酵}

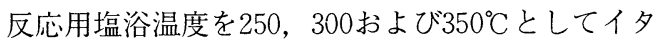
ジイを加圧熱水分解した時の結果を Fig. 7 に示す。 セルロースの場合は, 予熱処理として行った $250^{\circ} \mathrm{C}$, 3 分の処理ではほとんど分解されなかったが, イタジ イの場合は $250^{\circ} \mathrm{C}$ という穏和な温度でも分解し，60秒 後にはWSの最大収率34 wt％が得られた。WSの生 成ピークはセルロースほど単純なものでなく, 複数成 分の分解が起きている事が伺われた。またMS も反応 の比較的初期から生成しており, 七ルロースの場合と は異なる分解挙動を示した。ガスおよび揮発成分 $G$ は WS が減少する時に増加しており, 生成したWS の熱 的二次分解が起きていることが示された。加熱温度が 高くなるにつれ，反応速度は早くなり，MIの最小值 も減少して分解は進行するが, WS の収率は増加せず, G とWSがわずかに増加する傾向が見られた。

反応用塩浴温度を $250^{\circ} \mathrm{C}$ とし，加熱時間を $30 ， 60$, および300秒とした時のWS の HPLC クロマトグラム を Fig. 8 に示す。加熱開始後 30 秒でWS 収率は 23 wt\%に達したが，RIで検出された成分はUVにも吸 収を持っている事から，得られたWS は芳香族系の 化合物であることがわかった。すなわち反応の初期に おいては, ベンゼン・エタノール混合溶剤で抽出され なかったタンニン成分や, セルロースおよびへミセル ロースを覆うリグニン成分の 1 部が水可溶化されたも のと考えられる。リグニンに関しては, Antal らも考 察しているように5)6), アモルファスなリグニンが比 

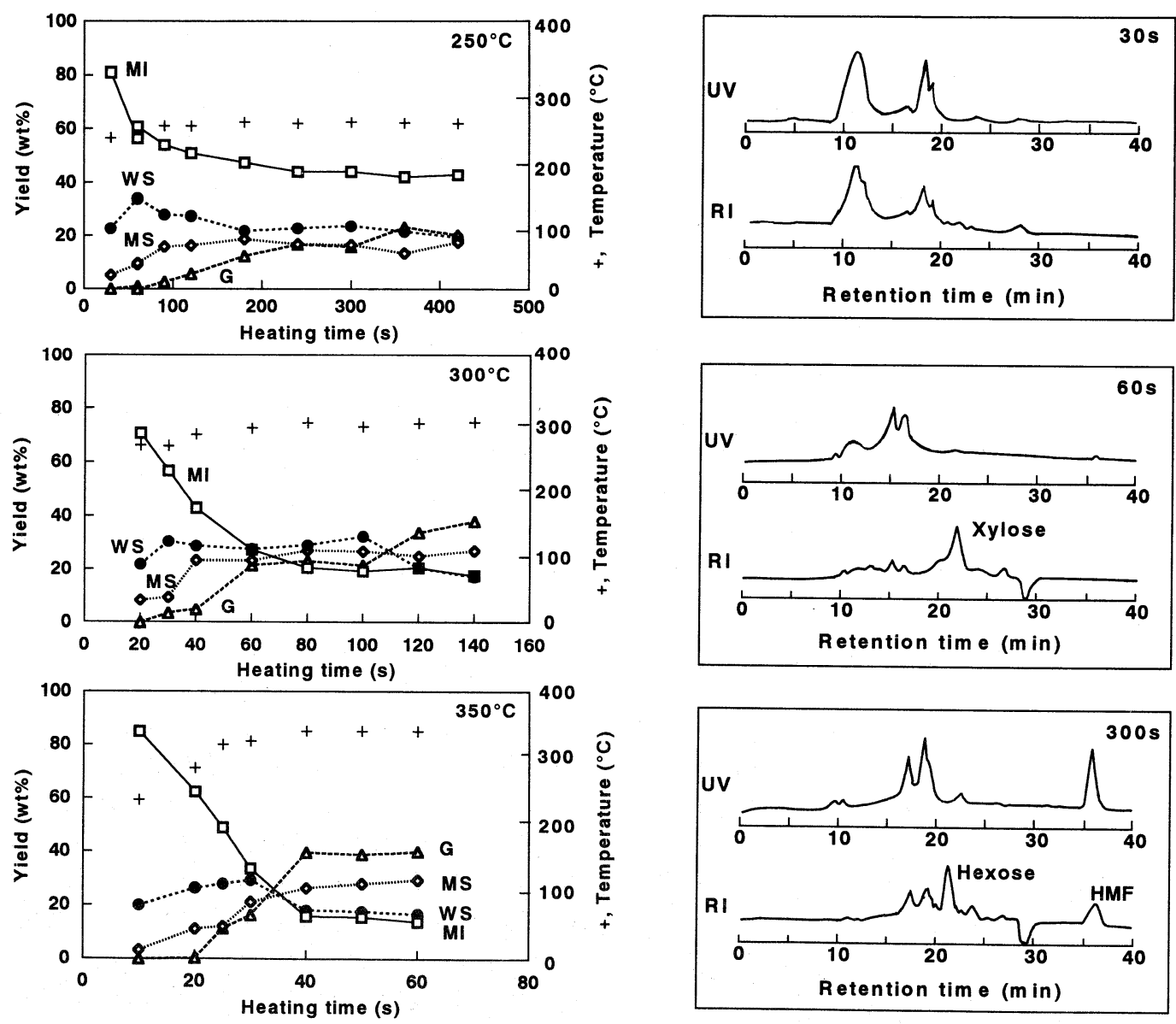

Fig.7 Decomposition of chinquapin in hot compressed water

較的低温で分解溶出したものであろう。加熱時間60秒 では，30秒のWS に現れていた溶出時間 9 ～13分の 大きなピークは小さくなり，代わりにへミセルロース の加水分解物であるキシロースが生成していた。

Fig. 7 において, WS の生成に少し遅れて MS が生成 している事からも, 初期に溶出した芳香族成分は極め て不安定であり，さらに加熱される事によりすぐに非 水溶化 (油化 ${ }^{11)}$ ) して MS 成分に変化した事が考え られる。また加熱時間300秒ではキシロースも消失し, セルロースの加水分解物であるヘキソースを第 1 成分 とするWS が得られた。反応用塩浴温度を $300^{\circ} \mathrm{C}$ とし た時のWS 中のキシロース, ヘキソースおよび HMF 濃度と加熱時間の関係を Fig. 9 に示す。これらの成 分は加熱時間に応じて順次生成しており，例えば加熱 時間を60秒とすれば，HMF 濃度を比較的低く抑えら れ，20 wt \%以上のヘキソース濃度の WS が得られる

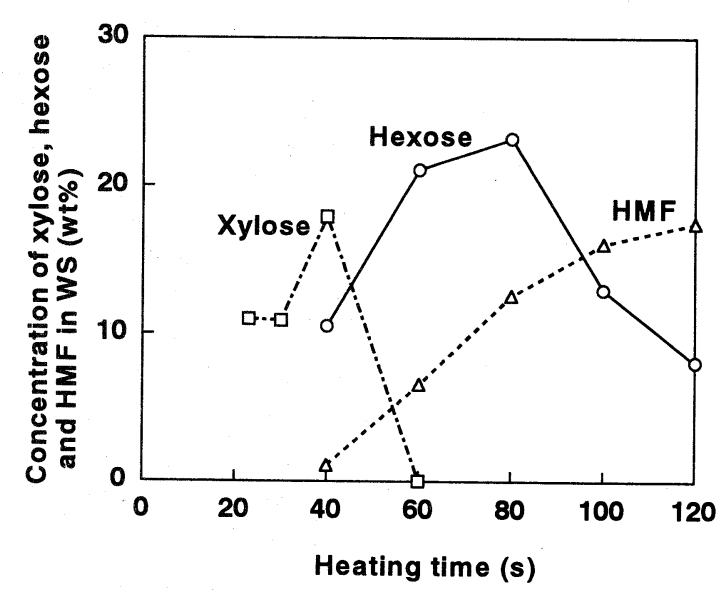

Fig.9 Change in composition of WS from chinquapin
with heating time

Fig.9 Change in composition of WS from chinquapin
with heating time

(Temp. of salt bath for reaction, $300^{\circ} \mathrm{C}$ )

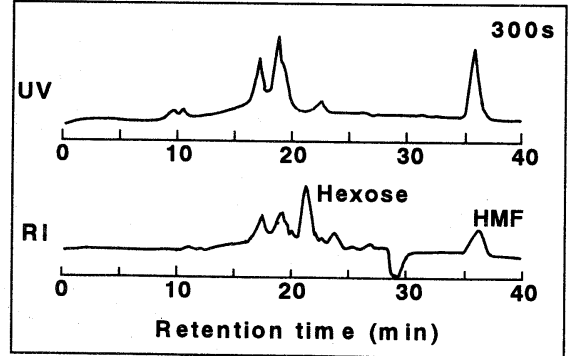

Fig.8 HPLC chromatograms for WS from chinquapin (Temp. of salt bath for reaction, $250^{\circ} \mathrm{C}$ ) (Temp. of salt bath for reaction,300' 
事が示された。この条件で得られた試料に対し，七ル ロースの場合と同様の活性炭処理を施し，アルコール 発酵試験を行った結果，発酵は順調に進行し，物資収 支もほほ成立する事を確認した。

次に MS 成分の性状を調べるため, $300^{\circ} \mathrm{C}, 100$ 秒の 処理で得られたWS，MS，MI，および $72 \%$ 硫酸不溶 分として採取したイタジイのリグニンの赤外吸収スペ クトルを測定し，その結果を Fig.10に示した。MSの スペクトルはWS のそれとは明らかに異なり，リグ ニンのそれと良く類似していた。また，セルロースか ら得られるWS は, 二次分解してGおよびMS，そし て更にはチャー状の MI に変化することは先に述べた が，今回得られたイタジイの MIは，IR スペクトル的 にはセルロース系のチャーではなく，むしろリグニン 系のものであった。すなわち, リグニンの中でも活性 な成分は容易に分解され, WS を経由して直ちにMS

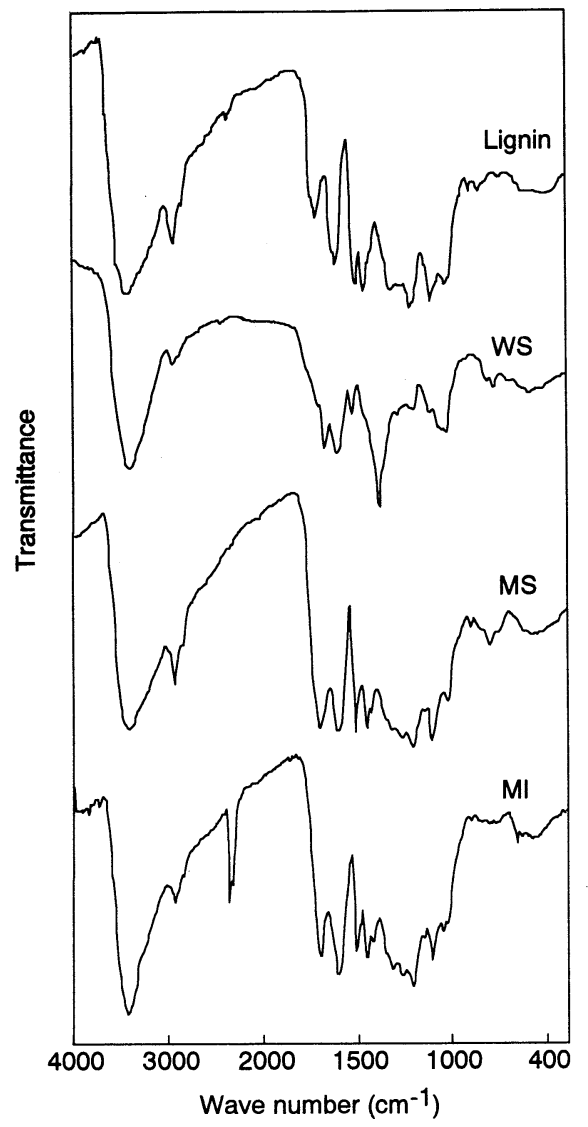

Fig.10 FTIR spectra for lignin, WS, MS and MI from chinquapin

(Temp. of salt bath for reaction, $300^{\circ} \mathrm{C}$, heating time, 100s)
に変化するが，リグニンの中でも安定で分解しにくい 成分は固形残渣として残り，少量のセルロース系 チャーと共にMI として得られたものと考えられる。

従って, リクニン系の分解物は MS として, ヘミセ ルロースやセルロースの分解物はWS としてそれぞ れ分取されるため，WS は発酵原料として利用できる。 以上のように広葉樹の場合は脱リグニン等の特別な前 処理を施さなくても，ヘミセルロースやセルロースを 加水分解できた。しかし，針葉樹の場合は，ここでは 述べなかったが，広葉樹と比較すると分解性が低く， かつWS 中の単糖濃度が低かった ${ }^{12)}$ 。これは Mok $ら^{5)}$ が指摘しているように，リグニンやセルロースの 結晶化度の違いによるものであろう。従って針葉樹に 関しては, リグニンに対する何らかの前処理を含めて 今後の課題である。

\section{4.まとめ}

セルロースおよび広葉樹のイタジイに対して加圧熱 水分解を行った結果，これらは速やかに分解し，その 水可溶分は酵母によるアルコール発酵原料として供す る事ができた。この方法は広葉樹に対しては脱リグニ ン等の特別な前処理を必要とせず, $250-300^{\circ} \mathrm{C}$ 程度の 加圧熱水のみで，ヘミセルロースやセルロースを数 10 秒から数分のオーダーで高速に糖化できる。単糖収率 をさらに高めることができれば，本プロセスは酵素分 解法や酸加水分解法に代わる新しいバイオマスの糖化 法として有望であると考える。

\section{文献}

1 ) 中尾勝寛, 化工誌，58，380（1994）

2 ) Bobleter, O., Niesner, R. and Rohr, M., J. Appl. Polym. Sci., 20, 2083 (1976)

3 ) Bonn, G., Concin, R. and Bobleter, O., Wood Sci, Technol, 17, 195 (1983)

4 ) Smith, F. G., Physical Geochemistry, p.335 (1963)

$5)$ Mok, W. S-L. and Antal, M. J., Jr., Ind. Eng. Chem. Res., 31, 1157 (1992)

$6)$ Allen, S. G., Kam, L. C., Zemann, A. J. and Antal, M. J., Jr., Ind. Eng. Chem. Res., 35, 2709 (1996)

$7)$ Adschiri, T., Hirose, S., Malaluan, R. and Arai, K., J. Chem. Eng. Jpn. 26, 676 (1993)

$8)$ Pfeifer, P. A., Bonn, G. and Bobleter, O. Biotechnol Lett., 6, 541 (1984)

$9)$ Sakaki, T., Shibata, M., Miki, T., Hirosue, H. and Hayashi, N., Energy Fuels, 10, 684 (1996) 
10) Sakaki, T., Shibata, M., Miki, T., Hirosue, H. and Hayashi, N., Bioresource Technology, 58, 197 (1996)

11）美濃輪智朗, 小木知子, 土手 裕, 横山伸也, 化 工論文集，18，131（1992）
12) Sakaki, T., Shibata, M., Miki, T. and Hirosue, H., Proceedings of the Second International Conference on Solvothermal Reactions, p. 180, Takamatsu (1996)

\title{
Saccharification of Cellulosic Biomass with Hot Compressed Water and Alcohol Fermentation
}

\author{
Tsuyoshi SAKAKI ${ }^{* 1}$, Masao ShIBATA ${ }^{* 1}$, Toshiharu MIKI*1, Seiji YASUdA ${ }^{* 1}$ \\ Hideharu HIROSUE $* 2$ and Nobuyuki HAYASHI $* 3$ \\ $\left(\begin{array}{ll}* 1 & \text { Kyushu National Industrial Research Institute } \\ * 2 & \text { Kagoshima Prefectural Instiute of Industrial Technology } \\ * 3 & \text { Faculty of Agriculture, Saga University }\end{array}\right)$
}

SYNOPSIS : - In order to convert cellulosic biomass to raw materials for alcohol fermentation, cellulose and a chinquapin, a hard wood, were hydrothermolyzed with hot compressed water in a batch reactor at temperatures between 250 and $405^{\circ} \mathrm{C}$.

Cellulose was quickly solubilized to water, and nearly $40 \%$ of cellulose could be saccharified to hexose by adjusting the heating time in the range of 13-30s at the heating temperature of $305-405^{\circ} \mathrm{C}$. As a result of fermentation test of the water soluble fraction, the fermentation rate was found to be remarkably improved by removing furfurals in the solution through an active carbon treatment, and further, good mass balance was confirmed between the consumed hexose and formed ethanol.

In the case of chinquapin, the hydrothermolysis started at lower temperature than pure cellulse. Active lignin was first decomposed, and then hemicellulose followed by cellulose was hydrolyzed to water solubles (WS), although stable lignin was hard to decompose and remained as solid residue (methanol insolubles, MI). An increase in the heating temperature caused the decrease in the yield of MI, but did not the increase in the yield of WS because of the second decomposition of WS. However, the WS including over $20 \%$ of hexose was obtained in the yield of near $30 \%$ by optimizing the heating time. Since species from lignin were obtained as methanol solubles separately from WS, the WS were suitable for the fermentation and ethanol was successfully produced with saccharomyces.

\section{Key Words}

Saccharification, Cellulosic biomass, Hot compressed water, Alcohol fermentation 